\title{
Strategies for Strengthening Social Capacity during the Pandemic: An Analysis of the LAZIS-Nahdlatul Ulama Philanthropy
}

\author{
Sulkhan Chakim ${ }^{1}$, Umi Solikhah ${ }^{2}$, Fauzi $^{3}$ \\ \{sulkhan@iainpurwokerto.ac.id $\left.{ }^{1}\right\}$ \\ State Institute of Islamic Studies (IAIN) Purwokerto ${ }^{1,3}$ \\ Universitas Muhammadiyah Purwokerto ${ }^{2}$
}

\begin{abstract}
The Covid-19 pandemic impacts on many social aspects such as poverty like poverty, health, education, socio-economy and religion. Indonesian government and mass organization (both relegious and non- relegious) made various attempt to provide protection. The involvement of the Nahdlatul Ulama (NU) in public awareness of health protocols and religious practices is essential, especially in strengthening the network of family resilience affected by Covid-19. This study aimeds to explore the strategies to strengthen the capacity of mosque-based rural Muslim communities. The research method implemented a qualitative design. Data collection techniques employed FGD and observation. The subjects of this study were LAZIS-NU daily administrators at the district level and community figures. The results of this study indicated that the strategies to strengthen the capacity of the Muslim community include: first, educational communication through the use of traditions in community ritual groups. Second, community empowerment with a rural partnership pilot project model; third, advocacy for mosque-based Muslim communities.
\end{abstract}

Keywords: Strategy, social capacity, muslim society, philanthrophy-LAZIS-NU

\section{Introduction}

The flourishing of Islamic philanthropic institutions in Indonesia, such as the Baznas and Lazis which were affiliated with various religious mass organizations shows an escalation in strengthening and development of religious activities whose target capital was the upper middle class and the implementation of empowerment was the weak or inadequate. However, in the Muslim countries, such as Egypt, Yurdania, Qatar, Saudi Arabia, and Kuwait, The philanthropic institutions compete each other and even overlapped in motivation and program ideas with private and voluntary institutions [1]. The situation in the Middle East almost experienced the same as in Indonesia. The New Order era was President Soeharto's reluctance to institutionalize the Zakat Institution, but he prefers other philanthropic institutions, such as Supersemar [2].

Unlike the situation in Indonesia, where the Muslim community was the largest in the world, the two different institutions based on religious philanthropy and CSR seem to play a role and work together in synergy [3]. In the context of Muslim social welfare, the space for actualization and state relations was very open, and in contrast to Malaysia, which emphasizes the Islamic economic movement [4]. This shows an increase in the participation of philanthrophy institutions that were growing rapidly in private institutions, BUMN, and 
government in the form of LAZIS and BAZNAS. In the context of its utilization, the activity program carried out by Dompet Dhu'afa and PKPU was accelerating community development and strengthening civil society [5].

The two institutions'roles have made fantastic progress, both in terms of income and distribution, in line with research on the concept of Zakat related to ownership and multifunctions, namely religious, social and economic [6]. In contrast to [7], LAZIS-MU's new strategy model, namely empowerment and social welfare, were used as a movement to solve household problems for Muhammadiyah members.

The role of philanthropic institutions in the Covid-19 pandemic storm era has been a threat, challenge, and opportunity for the outbreak of the increasing spread of virus clusters in Indonesian society. The impacts were on the health, social and economic sectors, as well as religion. The economic impact was the sector most affected by the pandemic. Consequently, it also inflluences the economy of the donors (Muzakki). However, the donors switched to other forms; infaq and sadaqah [7]. In this context, Zakat was employed as one of the foundations of the social and economic system of society [6][8], infaq and sadaqah too. In the context of the community affected by COVID-19, the community is fragmented in the form of vulnerability to poverty, health, unemployment, and family problems. Strengthening capacity is essential in implementing zakat, infaq, and sadaqah institution programs, which include strengthening individuals, organizations, and communities, forming capacity building models and programs, building synergy between actors and institutions. Community development, it includes processes, the achievements of changes in life and society where they identify the problems they experience, the bigger changes in equality, justice and attitudes, collective activities, and the processes are carried out by volunteers [9].

This study aimeds to analyze strategies for strengthening the institutional capacity and members of mosque-based groups; and enhancing individual abilities in knowledge, skills, and attitudes.

\subsection{Social capacity}

The success of community development programs is determined by two principles; establishing democratic decisions based on the needs and emotions of the community, and considering the character and leadership development of the community, which includes: 1) promoting active and representative groups of participants to have equal opportunities, 2) educating community groups on social issues and economic, socio-environmental and political influences framed by alternative actions, 3) institutionalizing different interests to plan the process and assist the desired endeavors to gain influence on progress various community groups, 4) increasing the capacity of community leadership and social organizations, 5) maintaining a willingness to utilize strategic space as an effort to support long-term sustainability and become a good society [10].

In strengthening the community's capacity, they could be independent when executing programs, both in the involvement of individuals, groups, and organizations, which could be used as social capital because they have resources. The relationship between these forms of social capital includes financial, social, physical, environmental, human, political, and cultural capital [11], as local assets and investments useful in the process of strengthening and empowering the community. However, collective action becomes an orientation that must be considered because sometimes it does not follow the vision and goals of its formulation. Participatory approaches and social capital coalitions are needed to carry out an effective assessment. The implementation of capacity identification covers individuals, organizations, 
and institutions [11]. The view that all individuals have the capacity is used as an asset principle that could contribute to the community. According to [12] regarding the assets framework which includes, (1) financial assets, (2) human capital, knowledge, and skills, (3) social capital was social networks owned by the community and organizations, which were invisible assets but it contributes to community empowerment programs.

\subsection{Decision making and social participation}

In the context of the decision-making process, it provides more opportunities for participants that the ability of stakeholders plays a limited role, which aims to ensure collaborative decision-making processes related to the balance of quality and balance of power. In the context of the balance of quality and power, it is necessary to take sides with vulnerable and weak community groups, so that they have the ability and strength [13], as an effort to be fully involved and participated [14]. It Emphasizes value and change, considered with the emergence of political relations in different groups in the form of interests, dilemmas, and rights that must be explored. Interest is not defined as a need or desire but understood as something to be aware of because it will become dominant and barrier [15] The public sphere of society which consists of different groups politically, socially and civilian is treated equally both in education programs, empowerment and as the advocated groups.

\section{Method}

This research was to question and explore the facts of the involvement of mosque-based social agents. The data collection method used was qualitative, the acceptability which allowed changes to be made in the interests of the meaning of the relationship between subjects. For the research objectivity, various forms of subjectivity must be avoided so it would not interfere with the research setting, especially when conducting Focus Group Discussions (FGD) with both administrators and communities, interviews, documentary studies, and participatory observation in data collection. The research targets were mosque-based communities in routine groups such as the yasinan, ratiban, lailatul ijtimak in Branch Deputy Majlis-NU (MWC-NU).

\section{Results and Discussion}

\subsection{Potential society: tradition and culture}

LAZIS-NU as one of the autonomous institutions, was born by Nahdhatul Ulama in the early 21 st century around 2004 at the 31 st congress at the Hajj Dormitory, Boyolali, Central Java to help the welfare of the people and raise social dignity through the utilization of Zakat, Infaq, Sadaqah (ZIS) and Corporate Social Responsibility (CSR) funds [16]. Its establishment was a sign of a new movement to pay attention to society, especially the Nahdhiyin community (NU Community) in the welfare sector, especially at the regional and national levels. Although the birth of LAZIS-NU could be considered late compared to other religious mass organizations, its existence and development had been moved to the village level or often referred to as subbranch activities. This massive formation and expansion could not be separated from the principle, al-Muhafadhah 'ala al-qadim al-shalih wa al-akhdu bi al-jadid al-ashlah that was 
maintaining old traditions that are still good (relevant) and taking new things a better strategy as a struggle strategy in facing the flow of change in the public sphere. The Nahdhatul Ulama (NU) religious style relies on the tradition of being used as a movement infrastructure in various fields of da'wah activities [17].

The tradition was interpreted as a tool that was widely used by the community which was useful as a catalyst for inculcating Islamic values and teachings [18]. In addition to being interpreted as a means, and not only interpreted [19] as doctrine but it also includes rituals and symbols used as objects of inheritance for posterity for centuries. If using Bourdieu's analysis in constructing social practices in public spaces and capital, Nahdhatul Ulama played a role through Lazis-NU built from the level of branches, sub-districts, districts, provinces to the Nahdhatul Ulama Board (PBNU). The infrastructure was an institutionalized Philanthropy which was carried out continuously. Along with the government's massive community empowerment program, it had not been able to reduce the poverty rate [20].

Nahdhatul Ulama (NU) contributed and was involved in encouraging the awareness of its citizens to be actively involved as alternative advocates during worsening education, unemployment, domestic violence and increasing criminal acts. In this context, efforts to make ritual movements became important and needed by the community to carry out massive communication and education, such as activities of yasinan, ratiban, maulid al Baranzi and others, which were traditional media that NU maintains [21]. The movement built and maintained by NU, to borrow a term [22] was a process of mobilization of private capital sources which aimed as a model of domination strategy. Economic power was not in wealth, but in the relations between wealth and the realm of economic relations, and constitutions which could inspire the personal development of special agents with special interests. The form of action implemented by LAZIS-NU was in the form of a guidebook disseminated to donors. In the context of an economic relationship, it could create needs and interests [15], because both would become obstacles that result in hostility and unhealthy competition. It was evidenced by several branch administrators who complained about the distribution of the Branch Representative Council which was not responsive to various interests in grass roots.

Tradition and culture could be used as a source of law in fiqh studies to become a spirit in strengthening social life. The strength and resilience of the existence of the organization and its congregation was the anchor of nationality and the supporting strength of the Unitary State of the Republic of Indonesia (NKRI). Program activities implemented by LAZIS-NU were conducted through educational communication channels by utilizing traditions in community ritual groups. All channels of this ritual activity were scattered throughout the countryside as a power base of LAZIS-NU. Several outreach activities for customer network development or muzaki, conveyed in these forums, which include a monthly income development report. For example, in Cilongok sub-district, the delivery of information related to problems with the CoinNU activity program was communicated through the congregation of ratiban and mujahadah at every Wednesday evening [23].

Unlike what was practiced in South Purwokerta with 7 (seven) NU branches, socialization activities were carried out through lailatul Ijtima'(selapanan or 35 days) as well as massively through the Whatsapp Group as a communication channel which was very helpful for various developments and problems [24]. Based on this data, to borrow Bourdieu's (1998: 16) theory that the processes carried out by NU through LAZIS-NU are a form of political capital that could provide guarantees as a form of private propriety and public services because the distribution was in the form of scholarships, health, training, agriculture and livestock, house renovation, and organizational strengthening. This activity could be called a process of patrimonialization of collective resources carried out by the elite. In this case, it was a form of 
elite social democracy in the strength of several generational structures. One of the things that could be studied was how the political type about social capital transmitted through networks of family relations, pesantren could not be separated from the dynastic power or kinship of the pesantren founders.

\subsection{The mosque-based institutional and group capacities}

The development of Zakat Institutions in Indonesia could be considered both encouraging and at the same time providing an illustration of increasing people's faith in Indonesia. Zakat regulation is based on Law No. 23 relating to Zakat Management as a substitution of Law No. $38 / 1999$, which provides more strength and certainty for the community. State involvement in zakat management raised suspicion among religious mass organization leaders, such as the assumption that management under the name's LAZ belonged to the community, while BAZ seemed to belong to the government [25]. In its development, the Islamic community experienced a double burden, the obligation to pay zakat and taxes on the enactment of Law no. 23 of 2011 and Law no. 36 of 2008. However, the most recent development was a reduction in tax obligations. It was based on the issuance of Governance Regulation Number 60 of 2010 which provides license on the obligations of the Muslim community.

\subsubsection{LAZIS-NU Banyumas}

LAZIS-NU Banyumas was established in 2014, - organized through the management of the Nahdahtul Ulama Branch Representative Council (MWC-NU) at the sub-district level. The socialization process was carried out in several ways, including: Lailatul ijtima ', which had a routine meeting activity at the PC NU, and MWC-NU levels. The LAZIS-NU management attended the lailatul ijtima' event was organized by MWC, and NU Subdistricts implemented about Zakat, Infaq, and Sadaqah guidelines, which was discussed the strategy for its preparation. The management of LAZIS-NU was continuously improved both in terms of organization, operations as an institution that manages community funds, especially that has been organized by the Nahdhiyin community [26].

\subsubsection{The implementation of program activities}

\subsubsection{Activities carried out by LAZIS-NU for mosque-based community groups}

The program of activities carried out by LAZIS-NU for mosque-based community groups was to provide stimulants to groups from 12 sub-districts by holding training on making natural nutrition with materials around the village environment used to process the manufacture of manure. These activities were centered in the Sukawera village, Cilongok sub-district, Banyumas.

\subsubsection{Program in the village of berkoh}

The inorganic waste of sorting program in the village of Berkoh, was an activity of a mosque-based Muslim group formed through the branch of the ZIS management unit. This activity was carried out with the motto of "sorting trash from the house" which was developed into annual savings and distributed in cash at Eid Al Fitr. This activity was based on information from several administrators about the beginning of its establishment by several people 
conducting a comparative study in the Wates Jogjakarta area regarding inorganic waste management. By this activity, the UPZ-NU management tried to hold regular discussions to plan the establishment of the Nine Star Waste Bank management and was accompanied by one of the waste management activists. Some of the activities carried out include socialization and education through the Muslima Masjid al Barakah recitation group, which had 12 recitation groups spread across the Neighborhood (RT) level [27]. In addition to learning about sorting techniques related to money-valued waste categories, several administrators also learned the calculation system using this excel training program, which is useful for calculating the savings of members of the Waste Bank.

\subsubsection{Elderly health post activity program}

The Mosque-Based Elderly Health Post activity program, was initiated by the Muslimat recitation group and UPZIS-NU administrators aiming to assist the elderly, especially related to health. This activity was designed every week in collaboration with students who were currently practicing at Margono Soekarjo hospital. To assist Muslim workers who voluntarily learned to use temperature and body tension measuring devices. In addition, the recording of the elderly was carried out in a health check book. These activities were funded by UPZIS-NU and al Barakah mosque infak cash [28].

\subsubsection{The baitul ikhlas}

The Baitul Ikhlas Muslim prayer group was given a program of activities for the skills to make broom sticks, mats and floor brooms. These activities were carried out by bringing in a trainer for 3 days, they felt happy and skillful. These activities did not continue due to motivational factors to change himself [29]. This training activity was an effort to educate the housewives recitation group which activated routinely for congregation tahlian every Friday afternoon. Efforts to strengthen skills aimed at increasing the ability of individuals and groups expected to provide added economic value to the family. Involvement in providing service unit (ZIS) funds was a form of stimulant, serving as education, directed at empowering and advocating for groups considered economically and socially vulnerable. According to [5] Dompet Dhu'afa and PKPU accelerated in developing and strengthening civil society through community activities with a structural approach. But the approach was different from taken by UPZIS-NU, namely by utilizing local traditions as social cohesiveness and instrument of program sustainability activities.

\subsubsection{The training of household laundry soap}

The muslimat of al Hidayah Sukawera recitation group was an Asmaul Khusna recitation group, Gunung Lurah village, Cilongok Subdistrict, holding training on making liquid soap for household kitchens. This activity was in collaboration with an institution engaged in community empowerment, Qaryah Barakah wa Rahmah. This laundry soap making training was expected to be a trigger for housewives who are economically empowered. However, the findings showed a weakness of this activity. This activity group did not a design them to be a driving agent or a pioneer. The activity welcomed enthusiastically by the mothers could not run as expectedly, meaning that the activity had not follow-up and only limited to knowledge. According to the information, efforts to mobility assets in the form of identifying groups that were driving agents have been carried out by the management qaryah barakoh wa rahmah as a social institution [21]. 
Theoretically, mentoring and strengthening asset groups was needed to become a driving catalyst. In this context, this catalyst really determined the sustainability of program. The social coalition efforts have actually been carried out by holding the qaryah barakah wa rahmah. Implementing the LAZIS-NU program used to two communities based on men and women routinly ritual activities was a process of incorporation and reproduction of cultural capital in the structure of social space [30]. The reproduction of the distribution of cultural space structures was achieved through the kinship strategy of the pesantren or alumni, which were the basis of power and something that is institutionally privileged for their social position. Social networks were conducted through group strength in sub-branches or villages and at the sub-district level through the Branch Representative Council (MWC-NU). This social space was utilized by NU as an effort to provide support to the organization, and individual.

\subsubsection{Mosque management training}

The mosque management activity program was carried out as an effort by LAZIS-NU to organize the administration of mosques and mosques as the basis for education, empowerment, and strengthening of the congregation in its surrounding. The mosque was used as a center of activities that orientated to support the congregation. Mosque administrators coordinate every activity after Friday prayers to coordinate and evaluate the implementation of UP-ZIS, CoinNU Care, and Waste Bank [31]. Several evaluations often aroused that problems occurred in the community, such as: The officers were not serious about withdrawing the NU Care Coin box resulting in the commitment of the customers being overdue and even the missing Coin Care box, and many congregations resigned. These two problems resulted in a lack of public trust to the managers due to lack of discipline, intensity of communication, and negligence of UP-ZIS administrators.

Organizational communication was needed by all groups of society both face interpersonal communications and media. The WAG media was used by NU branches and MWC-NU at the District level. But this media also was ineffective in strengthening the organizational communication network. Social networks were the strength of social capital because social agents or organizational figures played a role in their involvement, as argued by [32], [33] that social assets were invisible but could contribute to community empowerment programs.

\subsubsection{Training the care of muslim women corpses}

It was expected that the training program for the care of Muslim corpses to the mothers of the 12 recitation group members would be able to independently care for women's bodies (Interview, Shoburi, Darwati and Aisah, 19 July 2019) This activity could have an impact on awareness and increase the involvement of mothers. Based on field observations there were changes and involvement of mothers in the activity of covering bodies, especially women's bodies. Changes in individual perceptions and behavior were carried out through social groups act as agents of change.

\subsubsection{Posyandu cadre training program}

This activity involved the cadres of the recitation group and the posyandu activists in the Berkoh branch. The training materials include: physical examination methods related to weighing, height measurement, and nutrition for toddlers. Besides, training activities for elderly health post cadres include counseling for healthy elderly people, physically happy and mentally 
happy, measuring blood pressure and sugar level, as well as healthy living patterns (interview with Sumardiyah, Kundarti, Kuswuriyah, 25 July 2019). These activities were funded by UPZNU based on the congregation groups of mosques and mushala as well as prayer groups. Based on observations of the Posyandu Toddler and Elderly Health Post activities, both activities still existed and were ongoing. There were several findings why this activity was still existed and expected by the cadres because the cadres had a passion and social responsibility regarding the programs of the jama'ah. Likewise, there was a need for housewives for the health of children under five. Meanwhile, the elderly had needs for their vulnerability health. Beside these needs, it was because of the awareness to meet up, and to fill daily activities, and to have refreshing activities (Interview, Mangun, Karwen and Darsini, 27 July 2019).

The data above, provides the argument that efforts to maintain willingness by utilizing strategic space to support the long-term sustainability of the community were empowered [10]. Thus, strengthening the capacity of individuals, groups, and organizations could be built. In this context, an asset mobilization strategy could be implemented by utilizing different resources, both differences in interests and politics. As different interests would be a source of obstacles to the program's sustainability, and it would become a threat to organizational programs [31][32]. Human Capital is an asset that must be considered, because it could be used as a source of power and organizational strengthening. At least this capitalization is a contributing asset mobilization strategy. Bourdieu's different concepts [34][35] saw the efforts which were made by Nahdhatul ulama as a form of social, political and cultural practice that created a stronger image of the organization and stretched its reputation in the eyes of the community[36][37].

\section{Conclusion}

LAZIS-NU as one of the Philanthropic Institutions in Indonesia has a central strategy that could mobilize rural and urban communities through hundreds of years of institutionalized ritual-religious community traditions activities. These ritual institutions include; groups of yasinan, maulid al Barjanji, dhiba'i, ratiban, mujahadahan, istighatsah, manaqib, and others were used as tools for social movements which affect on group cohesiveness and loyalty.

These groups function as (1) communication and socialization forums for both program and program implementation, (2) strengthening membership in building organizational and religious awareness, (3) specific capacity strengthening targets for increasing business development in the area of mosque-based agriculture and animal husbandry through training in making natural nutrition, natural fertilizers, compost, and rural crop technology. The finding of the weaknesses in strengthening the community capacity is the lack of continuity and group managerial assistance to develop better.

\section{Acknowledgements}

This research was funded by LPPM IAIN Purwokerto (State Islamic Institute) for Rp. $26,000,000$. Interpretations and opinions are the author's responsibility, and may not be in accordance with the Covid-19 cluster regulations. 


\section{References}

[1] Barbara Lethem Ibrahim and Dina H. Sherif, From Charity to Social Change: Trends in Arab Philanthropy. the American University in Cairo Press, 2008.

[2] A. saepudin Jahar, "The Clash of Muslims and State: Waqf and Zakat inPost Independence Indonesia," Stud. Islam., vol. 13, no. 3, pp. 353-395, 2006.

[3] M. Ariff, The Muslim Private Sector in Southeast Asia. Singapura: ISEAS, 1991.

[4] S. Abbas, "The Strugle for recognition: Embracing The Islamic Welfare Effort in The Indonesian Welfare System.," Stud. Islam. Indones. J. Islam. Stud., vol. 12, no. 1, pp. 33-36, 2005.

[5] A. saepudin Jahar, "The Clash of Muslims and State: Waqf and Zakat inPost Independence Indonesia," Stud. Islam., vol. 13, no. 3, pp. 353-395, 2006.

[6] Euis Nurlaelawati, "Zakat and The Concept of Ownwership in Islam: Yusuf Qaradawi's Perspective on Islamic Economics," Al-Jami'ah, vol. 48, no. 2, pp. 367-385, 2010.

[7] Zakiyuddin Baidhawy, "Lazismu and RemarkingThe Muhammadiyahh's New Way of Philanthropi," Al-Jāmi'ah J. Islam. Stud., vol. 53, no. 2, pp. 387-412., 2015.

[8] H. Djatmiko, "Re-formulation zakat system as tax," Indones. J. Islam Muslim Soc., vol. 9, no. 1, p. 28.

[9] Michael Pitchford and Paul Henderson, Making space for community development. UK: The Policy Press, 2008.

[10] Susan H Burkholder and M. Chupp, "Principle of Neighborhood Planning for Community Development," p. 2003.

[11] Green Gary Paul and A. Haines, Asset Building and Community Development. CA: Sage Publications, 2007.

[12] M. Sherraden, Assets and the Poor. New York: Medscape, 1991.

[13] E. Suharto, Membangun Masyarakat, Memberdayakan Rakyat. Bandung: Aditama, 2007.

[14] Gary Paul Green and A. Gotting, Mobilizing Communities: Assets Building as a Community Develompment Strategy. Philadephia: templak University Press, 2010.

[15] S. Shardlow, The Values of Change in Social Work. Routledge, 2003.

[16] NU Care Lazisnu, LAZIS NU.org, Jawa Tengah, 2015.

[17] Robikin, "NU Lahir Mempertahankan Tradisi dan Khazanah Budaya Sumber.," mediaindonesia.com, Jan. 30, 2019.

[18] M. Baidlowi, "Bagaimana Pandangan NU terhadap Kebudayaan.," Republika.co.id, Oct. 23, 2019.

[19] S. Prickett and R. P. of E. L. S. Prickett, Modernity and the Reinvention of Tradition: Backing Into the Future. Cambridge University Press, 2009.

[20] Armida, "Kemiskinan di Indonesia dan Penanggulangannya," Bappenas, 2013.

[21] Tri Elok et al., "FGD Komunitas Sokawera, Pelatihan Pembuatan sabun cuci dapur, kegiatan pelatihan ini sangat baik dan para ibu sangat senang dan atusias karena akan menambah kegiatan pra ibu muslimat khususnya ibu rumah tangga, tetapi sayang sekali tidak ada yang menggerakkan yang mendampingi baik dari tim pelatih maupun UPZ," Sep. 08, 2019.

[22] P. Bourdieu and P. P. Bourdieu, Outline of a Theory of Practice. Cambridge University Press, 1977.

[23] Seno and Muzakkir, Jul. 05, 2019.

[24] Hanif and Suparman, "Program Kegiatan yang didanai oleh UPZ," Jul. 07, 2019.

[25] Iskan (lasQolba Lobist), "Tugas Berat di pundak BAZNAS," INFOZ, vol. 16, no. vii, p. 9, Feb. 2012.

[26] Ridwan (last), Bambang, Subur, and Supani, "FGD dengan pengurus LAZIS-NU Cabang," Oct. 07, 2019.

[27] Muhyidin et al., Agustus 2019.

[28] Sumardi et al., Agustus 2019.

[29] Darsini and Fitri, "Wawancara, (Darsini dan Fitri 7 Agustus 2019),” Agustus 2019.

[30] P. Bourdieu, Practical Reason: On the Theory of Action. Stanford University Press, 1998.

[31] I. Subiyakto, W. Amin, and Sugeng, "Rapat Pengurus Masjid al Barokah,” Nov. 08, 2019.

[32] J. P. Kretzmann, Building Communities from the Inside Out: A Path Toward Finding and Mobilizing a Community's Assets. Center for Urban Affairs and Policy Research, Northwestern University, 1993. 
[33] D. Fabiani and T. F. Buss, Reengineering Community Development for the 21st Century. Routledge, 2015.

[34] P. Bourdieu, Practical Reason on the Theory of Action. California: Stanford University Press, 1998.

[35] P. Bourdieu, Outline of A theory of Practice. Cambridge: University Press, 2007.

[36] T. Hannah, The Assets Framework: Moving Toward Transfomative Transactions. New York: M.E. Aharpe, 2008.

[37] D. C. Dabija, "Organizational Culture and Reputation - Vectors in Shaping Successful Retail Brand Value,” SSRN Electron. J., 2012, doi: 10.2139/ssrn.2232914. 